Ivo Badal

\title{
Vztahy mezi účastníky obnovy památek
}

Klíčová slova: Památková péče; Obnova památek; Účastníci obnovy.

Kontakt: badal.I@fce.vutbr.cz

Školitel: Josef Hrabec

Tematický okruh: Architektura

\section{Relations among Heritage Restoration Stakeholders}

Today, heritage conservation is a problematic process from the point of view of the legislative framework as well as the relations among the stakeholders. The Act on Heritage Conservation, still in force, was adopted in 1987. Since then, several amendments to this Act have been made to reflect changes in related legislation (the Code of Administrative Procedure, the Building Act, the Civil Code, harmonisation with EU legislation,...); nevertheless, the Act on Heritage Conservation does not respond to all of the heritage conservation needs in the context of the current economic situation and situation in society. 
Cílem disertační práce je analyzovat problematiku památkové péče z pohledu stávající platné legislativy.

Celý proces aplikace památkové péče je v současnosti problematický z pohledu legislativního rámce i vztahů mezi jednotlivými účastníky obnovy památek. Platný zákon o památkové péči je z roku 1987. Několikrát byl tento dílčím způsobem novelizován z důvodu zapracování navazujících právních norem (správní řád, stavební zákon, občanský zákoník, soulad s právními normami Evropské unie...), přesto ne zcela reaguje na současné potřeby památkové péče s přihlédnutím ke společenské i ekonomické situaci.

Nový zákon o ochraně památkového fondu je v současnosti ve stadiu připraveného konceptu paragrafového znění včetně závěrečné zprávy z hodnocení dopadů regulace podle obecných zásad (RIA) a je připraven k projednání vládou s předpokládaným termínem nabytí účinnosti 1. 1. 2018.

Problematika vzájemných vztahů účastníků obnovy památek se dotýká nejen orgánů veřejné správy, ale především velmi širokého okruhu subjektů, vlastníků kulturních památek a vlastníků nemovitostí ležících v památkově chráněných územích. Společně s nimi se proces obnovy památek dále týká především projektantů a realizačních firem podílejících se na konkrétních akcích obnovy.

Z pohledu všech zúčastněných stran se jedná o složitý proces vzájemných vztahů, který by měl v souladu s platnou legislativou vyústit v ochranu, zachování a optimální zhodnocení památek po stránce urbanisticko-architektonické, historicko-umělecké, provozní i stavební.

Je třeba se zamyslet nad definicí památky a prohlašováním památek, formou evidence, stupni a formami památkové ochrany i prŕstupem $\mathrm{k}$ historizujícím objektům a strukturám mimo památkovou ochranu. Současně je vhodné se inspirovat v okolních zemích s dlouhodobou tradicí památkové péče (Francie, Anglie). Podstatná je vyváženost práv a povinností majitelů památkově chráněných objektů a dosažitelnost dotačních titulů a finančních zvýhodnění při obnově, ale zejména údržbě památkově chráněných objektů. A v neposlední řadě je to problematika vzdělávání v oboru památkové péče.

Informace a data pro zpracování disertační práce budou získány formou konzultací s odborníky zapojenými do legislativního procesu, pracovníky v oblasti uplatňování památkové legislativy, investory, architekty, projektanty obnovy konkrétních památkově chráněných staveb a zástupci realizačních stavebních firem. Součástí disertační práce bude dílčí databáze konkrétních staveb památkové obnovy s historií jejich přípravy a realizace a hodnocením průběhu obnovy z pohledu majitele-investora, projektanta, dodavatele a zástupců výkonných orgánů památkové péče. 


\section{SOUPIS ZDROJU゚}

DVOŘÁK, Max. Katechismus památkové péče. 1.vyd.Praha: Národní památkový ústav, 2004, ISBN 80-86234-55-X.

HÁJEK, Tomáš. Zánik a vznik památkových péćí. 1. vyd. Praha: Nakladatelství epocha, 2005, ISBN 80-86328-71-6.

HLOBIL, Ivo. Na základech konzervativní teorie české památkové péče. 1.vyd. Praha: Národní památkový ústav, 2008, ISBN 978-80-87104-32-3.

HOLEČEK, Josef a kol. Projektování obnovy stavebních památek. 1. vyd. Praha: Národní památkový ústav, 2008, ISBN 978-80-87104-34-7.

KIESOW, Gottfried. Památková péče v Německu. 1.vyd. Brno: Nakladatelství Barristel a Principal ve spolupráci s NPÚ, 2012, ISBN 978-80-87474-54-9.

PEK, Tomáš. Stavební památky. 1. vyd. Praha: Nakladatelství Wolters Kluwer, 2009, ISBN 978-80-7357-462-8.

RIEGL, Alois. Moderní památková péče. 1. vyd. Praha: Národní památkový ústav, 2003, ISBN 80-86234-34-7.

WAGNER,Václav. Umělecké dílo minulosti a jeho ochrana. 1. vyd. Praha: Národní památkový ústav, 2005, ISBN 80-86234-72-X.

.www.mkcr.cz $\quad(13.06 .2015)$

.www.npu.cz $\quad(13.06 .2015)$

\section{FOTOGRAFIE}

Foto: archiv autora 

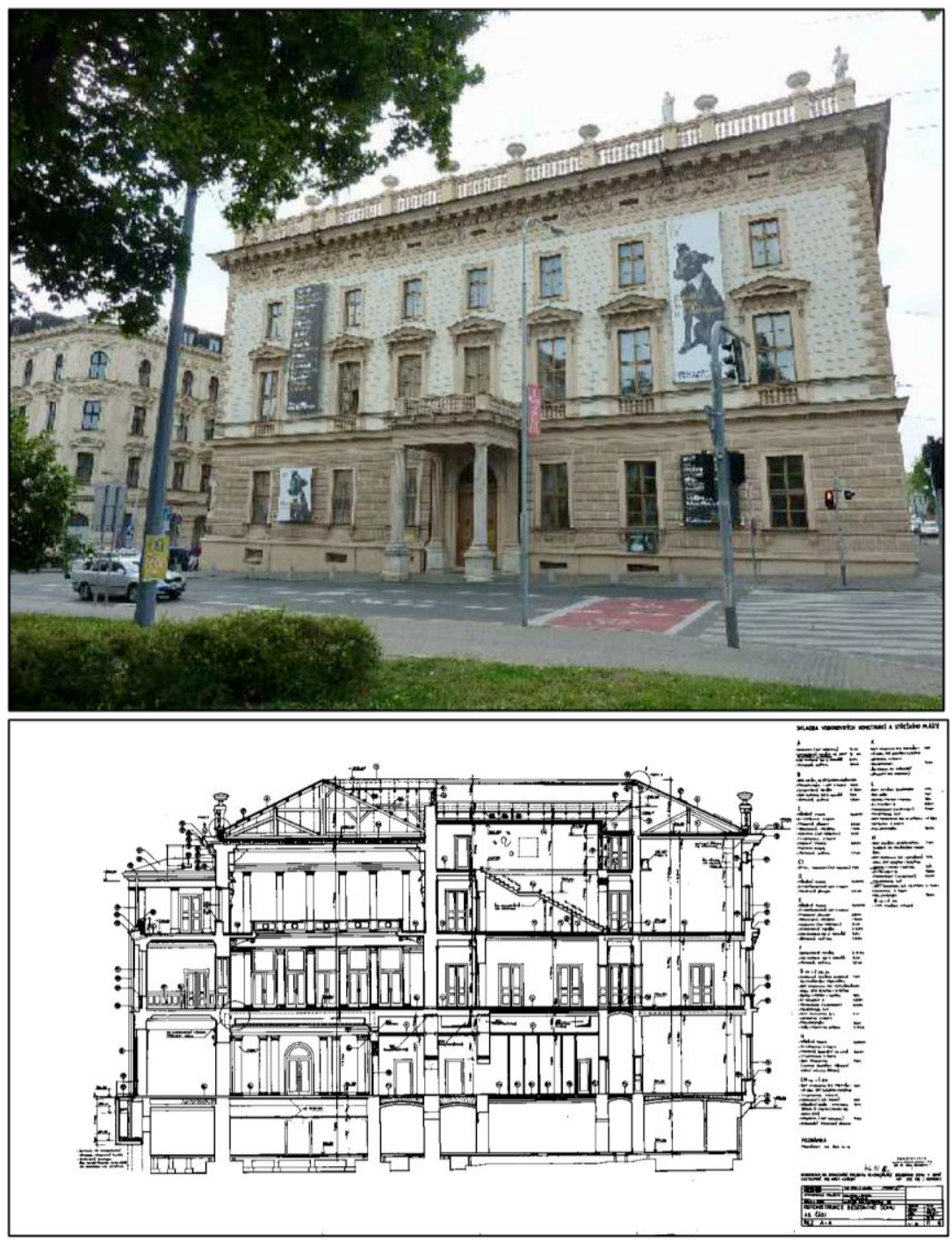

\section{BESEDNÍ DŮM V BRNĚ - 20 LET PO REKONSTRUKCI}

INVESTOR:

STÁTNI FILHARMONIE BRNO,

ZASTOUPENÁ BRNOINVESTOU

DODAVATEL STAVBY:

CESKOMORAVSKÁ STAVEBNI, S.R.O.
PROJEKTANT:

KONSORCIUM PROJEKTANTÚ HIP: DOC.ING. JULIUS KOMÁREK ING.ARCH. JINDŘICH KANĚK, ING.ARCH. LADISLAV MÜLLER ING.ARCH IVO BADAL, ING.ARCH, VILMA KAÑKOVÁ

KONZULTANT PAMÁTKOVÉ PÉČE: REALIZACE PROF. DR. MILOŠ STEHLIKK 1993 - 1995 